удк 342.9

DOI https://doi.org/10.32837/pyuv.v0i1(30).527

О. І. Миколенко

orcid.org/0000-0002-9755-9454

доктор юридичних наук, професор,

завідувач кафедри адліністративного та господарського права

Одеського національного університету ілені I. I. Мечникова

\title{
ЕФЕКТИВНІСТЬ АДМІНІСТРАТИВНО-ПРАВОВОГО МЕХАНІЗМУ РЕАЛІЗАЦІЇ ПРАВ ОСІБ У СФЕРІ МІСЦЕВОГО САМОВРЯДУВАННЯ
}

Постановка проблеми. Коли йдеться про ефективність адміністративно-правового механізму реалізації прав і свобод осіб у сфері місцевого самоврядування, то виникає необхідність визначення критеріїв такої ефективності. Підходи в даному випадку можуть бути різними:

1) виявлення шляхом проведення соціологічних опитувань серед громадян, які звертались до органів місцевого самоврядування з метою отримання адміністративних послуг чи реалізації інших прав і свобод людини та громадянина, рівня вдоволеності чи невдоволеності громадян діяльністю органів місцевого самоврядування. Оцінка громадськості не завжди є об'єктивною, але вона вказує на наявність чи відсутність авторитету влади на місцях;

2) встановлення через аналіз статистичних даних про діяльність органів місцевого самоврядування щодо розгляду звернень громадян та надання адміністративних послуг процентного співвідношення між загальною кількістю звернень та кількістю, наприклад, відмов у задоволенні звернень громадян. Така статистика, як правило, свідчить про об'єм виконаної органами місцевого самоврядування роботи за певний період (місяць, квартал, рік, п'ять років, тощо) і лише частково характеризує ефективність їхньої роботи;

3) виявлення через аналіз статистики діяльності адміністративних судів України (статистичні дані про кількість звернень в адміністративний суд щодо рішень, дій та бездіяльності органів місцевого самоврядування, про кількість рішень суду, в яких в повному обсязі були задоволені позовні вимоги і ін.) недоліків у діяльності органів місцевого самоврядування щодо реалізації прав i свобод особи. Значна кількість таких недоліків буде свідчити про низький рівень ефективності діяльності органів місцевого самоврядування, тоді як відсутність недоліків чи незначна їх кількість про високий рівень ефективності їх діяльності.

Запропоновані вище критерії та підходи дозволяють лише констатувати факт наявності чи відсутності ефективності в адміністративно-правовому механізмі реалізації прав і свобод особи у сфері місцевого самоврядування, але не дозволяють визначитись із подальшими напрямами вдоскона- лення діяльності органів місцевого самоврядування в окресленій сфері.

У зв'язку із цим важливим бачиться розкриття ефективності адміністративно-правового механізму реалізації прав і свобод особи у сфері місцевого самоврядування як явища правової дійсності.

Аналіз останніх досліджень і публікацій. Серед вітчизняних науковців, які займалися проблемою підвищення ефективності правового регулювання та діяльності органів влади, слід відзначити таких, як Н.Я. Бадахов, С.В. Бобровник, О.А. Котенко, Я.І. Ленгер, О.В. Мазурік, О.М. Мельник, Д.В. Олійник, Н.М. Оніщенко, Д.М. Павлов та ін. Разом із тим проблема визначення та підвищення ефективності діяльності органів місцевого самоврядування і сьогодні залишається недостатньо розробленою. Проблема ж визначення ефективності адміністративно-правового механізму реалізації прав і свобод особи у сфері місцевого самоврядування взагалі залишається недослідженою в науці адміністративного права та процесу. І пояснюється це відсутністю як методики оцінки ефективності діяльності місцевих органів влади, так і методики визначення ефективності адміністративно-правового механізму реалізації праві i свобод особи.

Постановка завдань. Основними завданнями, розв'язанню яких присвячена ця стаття, є такі:

1) охарактеризувати фактори, що зумовлюють ефективність адміністративно-правового механізму реалізації праві і свобод особи у сфері місцевого самоврядування;

2) визначити ознаки, що характеризують ефективність адміністративно-правового механізму реалізації праві і свобод особи у сфері місцевого самоврядування.

Виклад основного матеріалу. Ефективність адміністративно-правового механізму реалізації прав і свобод особи у сфері місцевого самоврядування є явищем правової дійсності, для розкриття змісту якого необхідно звернутися до характеристики наступних його особливостей.

По-перше, адміністративно-правовий механізм реалізації прав і свобод особи у сфері місцевого самоврядування безпосередньо пов'язаний із природою самої людини, громадянством особи 
та їі вчинками. Саме тому адміністративно-правовий механізм здійснює суттєвий вплив на поведінку особи, встановлює межу та обсяг реалізації iii прав і свобод, пропонує способи задоволення різноманітних потреб індивідів тощо. У сфері місцевого самоврядування реалізуються як права людини (наприклад, право на повагу до її гідності - ст. 28 Конституції України, право на свободу думки і слова, на вільне вираження своїх поглядів і переконань - ст. 34 Конституції України), так і права громадянина (зокрема, право особисто звертатися до органів місцевого самоврядування та їхніх посадових і службових осіб, що зобов'язані розглянути звернення і дати обгрунтовану відповідь у встановлений законом строк - ст. 40 Конституції України). Тому першочерговим споживачем послуг у сфері місцевого самоврядування щодо реалізації конституційних та інших прав особи є пересічний громадянин, який формує первинну оцінку про якість та ефективність діяльності органів місцевого самоврядування.

По-друге, адміністративно-правовий механізм реалізації прав і свобод особи у сфері місцевого самоврядування закріплюється національним законодавством. Наприклад, до правових джерел, які закріплюють перелік та порядок реалізації прав і свобод особи у сфері місцевого самоврядування, окрім Конституції України, відносяться Закони України «Про звернення громадян» [1], «Про доступ до публічної інформації» [2], «Про участь громадян в охороні громадського порядку i державного кордону» [3], «Про адміністративні послуги» [4] та інші нормативно-правові акти. Разом із тим до цього часу не був прийнятий ні Адміністративно-процедурний кодекс України, ні Закон «Про адміністративну процедуру». Тобто механізм реалізації прав і свобод особи у сфері місцевого самоврядування закріплюється чинним законодавством, яке, у свою чергу, має суттєві прогалини у правовому регулюванні суспільних відносин щодо процедур реалізації праві i свобод особи. Таким чином, за відсутності в Україні ефективного адміністративно-правового регулювання сфери реалізації прав і свобод особи відсутній і ефективний адміністративно-правовий механізм їх реалізації.

По-третє, процес правоутворення адміністративно-правового механізму реалізації прав і свобод особи у сфері місцевого самоврядування розпочинається з юридичного мотиву, тобто з уявлень, думок, поглядів про певну групу соціальних зв' язків та варіанти поведінки учасників суспільних відносин, які слід регламентувати в положеннях національного законодавства. У зв'язку із цим виникає доречне питання: «Адміністративно-правовий механізм повинен формуватися з огляду на особливості організації місцевого самоврядування в Україні чи з урахуванням прав і свобод людини та громадянина, проголошених у Конституції та закріплених у законах України?». Подібне питання виникало свого часу і стосовно принципів формування громадянського суспільства, тобто ініціатива повинна надходити «зверху» - від суб'єктів владних повноважень (Президента, Верховної Ради, Кабінету Міністрів України) чи «знизу» від громадськості (пересічних громадян та громадських об'єднань). Наприклад, у Росії інститути громадянського суспільства почали створюватись за ініціативою та під пильним контролем вищих органів державної влади Російської Федерації. В Україні пішли іншим шляхом - інститути громадянського суспільства формувалися знизу без підтримки органів державної влади. Нi в Росії, ні в Україні так і не були створені справжні інститути громадянського суспільства. У Росії інститути громадянського суспільства стали продовженням інститутів державної влади, а в Україні вони стали «іграшками» транснаціональних корпорацій та окремих олігархів. Тобто, з одного боку, Україна як держава втратила контроль за цими процесами, а з іншого боку, українське суспільство не було готове до нових взаємостосунків між державою та громадянином. Цим вдало скористалися інші сили у своїх інтересах. Отже, процес формування інститутів громадянського суспільства повинен відбуватись 3 ініціативи суспільства, держава ж повинна моніторити тенденції, що відбуваються у цій сфері, задля недопущення в системі інститутів громадянського суспільства чужорідних елементів, що загрожують незалежності та суверенітету країни. Подібна ситуація виникла сьогодні і з адміністративно-правовим механізмом реалізації прав і свобод особи у сфері місцевого самоврядування. Якщо такий механізм буде формуватися виходячи з інтересів функціонування органів місцевого самоврядування, то він буде мати суттєві вади. Наприклад, він буде максимально зручним для службовців органів місцевого самоврядування і мінімально зручним для осіб, які будуть намагатися реалізувати свої права і свободи шляхом звернення до цих органів. I, навпаки, якщо адміністративно-правовий механізм буде формуватися виходячи тільки з інтересів пересічних громадян, то матеріально-організаційний потенціал органів місцевого самоврядування не впорається з навантаженням, яке, на думку пересічних громадян, на них слід покласти. Таким чином, під час формування адміністративно-правового механізму реалізації прав і свобод особи слід враховувати:

1) не тільки інтереси осіб у публічно-правовій сфрері, а й уявлення, думки та погляди громадян про види, форми та способи реалізації їхніх прав і свобод у сфері місцевого самоврядування. Тому відображення адміністративно-правового механізму реалізації прав і свобод особи у їі ідеалах, свідомості, установках і світосприйнятті є важли- 
вою психологічною підставою його ефективності. У цьому аспекті важливим $є$ те, що ефективність адміністративно-правового механізму залежить від громадянина, а не від умов правового, політичного, економічного чи соціокультурного характеру, в яких він перебуває;

2) матеріально-організаційні можливості органів місцевого самоврядування. Тобто йдеться не про корпоративні інтереси муніципальних службовців, упровадження яких дуже часто негативно відображається на ефективності органів місцевого самоврядування, а про оптимізацію діяльності цих органів: а) виважена кадрова політика та кадрове забезпечення органів місцевого самоврядування; б) зумовлена функціями органів місцевого самоврядування структура виконавчих органів місцевих рад (наприклад, ст. 54 Закону України «Про місцеве самоврядування» передбачає можливість створення при місцевих радах відділів, управлінь та інших виконавчих органів для здійснення повноважень, що належать до їх відання [5]). Оптимізація органів місцевого самоврядування не повинна зводитись до банального скорочення «зайвих» кадрів чи «лишніх» структурних підрозділів, що неодмінно негативно позначиться на ефективності їхньої діяльності в тому числі і у сфері реалізації прав і свобод громадян.

Таким чином, ефективність адміністративно-правового механізму реалізації прав і свобод осіб у сфері місцевого самоврядування характеризується такими ознаками:

1) є оціночною категорією, за допомогою якої встановлюється рівень ефективності як взагалі адміністративно-правового механізму реалізації прав та свобод громадянина, так і окремих сфер життєдіяльності, наприклад, ефективність адміністративно-правового регулювання порядку реалізації праві і свобод особи чи ефективність діяльності органів місцевого самоврядування;

2) залежить від рівня правосвідомості громадян, що звертаються до органів місцевого самоврядування для реалізації своїх прав і свобод та рівня правової культури службовців органів місцевого самоврядування;

3) залежить від матеріально-організаційних можливостей органів місцевого самоврядування;

4) дозволяє простежити перетворення закріплених у національному законодавстві прав і свобод особи в реальне життя, а саме у сфері місцевого самоврядування, а також визначити, на якому етапі виконання такий механізм втрачає свою ефективність;

5) дозволяє простежити динаміку правових засобів, які використовуються у процесі забезпечення реалізації прав і свобод особи, з точки зору оперативності, упорядкованості та гнучкості (взаємозамінності).
Висновки та перспективи подальших розвідок. На підставі проведеного дослідження можна зробити такі висновки.

Адміністративно-правовий механізм реалізації прав і свобод особи у сфері місцевого самоврядування безпосередньо пов'язаний із природою самої людини, громадянством особи та її вчинками. Саме тому адміністративно-правовий механізм здійснює суттєвий вплив на поведінку особи, встановлює межу та обсяг реалізації їі прав і свобод, пропонує способи задоволення різноманітних потреб індивідів тощо. Першочерговим же споживачем послуг у сфері місцевого самоврядування щодо реалізації конституційних та інших прав особи є пересічний громадянин, який формує первинну оцінку про якість та ефективність діяльності органів місцевого самоврядування. Така оцінка не завжди є об'єктивною, але вона вказує на наявність чи відсутність авторитету влади на місцях.

Адміністративно-правовий механізм реалізації прав і свобод особи у сфері місцевого самоврядування закріплюється національним законодавством. На жаль, чинне законодавство має суттєві прогалини у правовому регулюванні суспільних відносин щодо процедур реалізації праві і свобод особи. Таким чином, відсутність в Україні ефективного адміністративно-правового регулювання негативно відображається і на рівні ефективності адміністративно-правового механізму реалізації прав i свобод особи у сфері місцевого самоврядування.

Під час формування адміністративно-правового механізму реалізації прав і свобод особи слід враховувати: 1) уявлення, думки та погляди громадян про види, форми та способи реалізації їх прав і свобод у сфері місцевого самоврядування; 2) матеріально-організаційні можливості органів місцевого самоврядування.

Ефективність адміністративно-правового механізму реалізації прав і свобод осіб у сфері місцевого самоврядування характеризується такими ознаками: 1) є оціночною категорією, за допомогою якої встановлюється рівень ефективності як взагалі адміністративно-правового механізму реалізації прав та свобод громадянина, так і окремих сфер життєдіяльності, наприклад, ефективність адміністративно-правового регулювання порядку реалізації праві і свобод особи чи ефективність діяльності органів місцевого самоврядування; 2) залежить від рівня правосвідомості громадян, що звертаються до органів місцевого самоврядування для реалізації своїх прав і свобод, та рівня правової культури службовців органів місцевого самоврядування; 3) залежить від матеріально-організаційних можливостей органів місцевого самоврядування; 4) дозволяє простежити перетворення закріплених у національному законодавстві прав і свобод особи в реальне життя, а саме у сфері 
місцевого самоврядування, а також визначити, на якому етапі виконання такий механізм втрачає свою ефективність; 5) дозволяє простежити динаміку правових засобів, які використовуються у процесі забезпечення реалізації прав і свобод особи, з точки зору оперативності, упорядкованості та гнучкості (взаємозамінності).

\section{Jimepamypa}

1. Про звернення громадян : Закон України від 02.10.1996. Відомості Верховної Ради України. 1996. № 47. Ст. 256.

2. Про доступ до публічної інформації : Закон України від 13.01.2011. Відолості Верховної Ради України. 2011. № 32. Ст. 314 .

3. Про участь громадян в охороні громадського порядку і державного кордону : Закон України від 22.06.2000. Відомості Верховної Ради України. 2000. № 40. Ст. 338 .

4. Про адміністративні послуги : Закон України від 06.09.2012. Відомості Верховної Ради України. 2013. № 32 . Ст. 409.

5. Про місцеве самоврядування : Закон України від 21.05.1997. Відомості Верховної Ради України. 1997. № 24. Ст. 170.

\section{Анотація}

Миколенко О. I. Ефективність адміністративно-правового механізму реалізації прав осіб у сфері місцевого самоврядування. - Стаття.

У статті розкрито фактори та ознаки, що визначають ефективність адміністративно-правового механізму реалізації праві і свобод особи у сфері місцевого самоврядування. Наголошено, що першочерговим споживачем послуг у сфері місцевого самоврядування щодо реалізації конституційних та інших прав особи $е$ пересічний громадянин, який формує первинну оцінку про якість та ефективність діяльності органів місцевого самоврядування. Така оцінка не завжди є об'єктивною, але вона вказує на наявність чи відсутність авторитету влади на місцях. Констатується, що відсутність в Україні ефективного адміністративно-правового регулювання негативно відображається і на рівні ефективності адміністративно-правового механізму реалізації прав і свобод особи у сфері місцевого самоврядування. Зроблено висновок, що ефективність адміністративно-правового механізму реалізації прав і свобод осіб у сфері місцевого самоврядування характеризується такими ознаками: 1) є оціночною категорією, за допомогою якої встановлюється рівень ефективності як взагалі адміністративно-правового механізму реалізації прав та свобод громадянина, так і окремих його елементів; 2) залежить від рівня правосвідомості громадян, що звертаються до органів місцевого самоврядування для реалізації своїх прав і свобод, та рівня правової культури службовців органів місцевого самоврядування; 3) залежить від матеріально-організацій- них можливостей органів місцевого самоврядування; 4) дозволяє простежити перетворення закріплених у національному законодавстві прав і свобод особи в реальне життя, а саме у сфері місцевого самоврядування, а також визначити, на якому етапі виконання такий механізм втрачає свою ефективність; 5) дозволяє простежити динаміку правових засобів, які використовуються у процесі забезпечення реалізації прав і свобод особи, з точки зору оперативності, упорядкованості та гнучкості.

Ключові слова: адміністративно-правовий механізм, реалізація прав і свобод особи, місцеве самоврядування, ефективність адміністративно-правового механізму.

\section{Summary}

Mykolenko O. I. Efficiency of the administrative and legal mechanism of implementation of personal rights in the field of local self-government. - Article.

The article reveals the factors and features that determine the effectiveness of the administrative and legal mechanism for the realization of the rights and freedoms of the individual in the field of local self-government. It is emphasized that the primary consumer of services in the field of local self-government in the implementation of constitutional and other personal rights is the average citizen, who forms an initial assessment of the quality and efficiency of local self-government. Such an assessment is not always objective, but it indicates the presence or absence of local authority. It has been established that the lack of effective administrative and legal regulation in Ukraine is negatively reflected in the level of efficiency of the administrative and legal mechanism for the realization of individual rights and freedoms in the field of local self-government. It is concluded that the effectiveness of the administrative and legal mechanism for the implementation of the rights and freedoms of individual in the field of local self-government is characterized by the following features: 1 ) is an assessment category with the help of which, the level of effectiveness of the administrative and legal mechanism for the implementation of the rights and freedoms of a citizen in general and in separate elements is established; 2) depends on the level of legal awareness of citizens who apply to local governments to exercise their rights and freedoms and the level of legal culture of employees of local governments; 3 ) depends on the material and organizational capabilities of local governments; 4) allows to trace the transformation of the rights and freedoms enshrined in the national legislation into real life, namely, in the field of local self-government, as well as to determine at what stage of implementation such a mechanism loses its effectiveness; 5) allows us to trace the dynamics of legal means used in the process of ensuring the realization of individual rights and freedoms, in terms of efficiency, orderly and flexibility.

Key words: administrative and legal mechanism, realization of individual rights and freedoms, local selfgovernment, efficiency of the administrative and legal mechanism. 